\title{
Nutritional Evaluation of Unripe Plantain, Moringa Seed and Defatted Sesame Seed Cookies
}

\author{
Mopelola A. Sodipo ${ }^{a^{*}}$, Matthew O. Oluwamukomi ${ }^{\mathrm{a}}$, Zianab A. Oderinde ${ }^{\mathrm{a}}$, And \\ OlugBenga O. AwOlu \\ ${ }^{\text {a }}$ Federal University of Technology, Akure, School of Agriculture and Agricultural Technology, Department of \\ Food Science and Technology, Ondo State, Nigeria \\ ${ }^{*}$ Corresponding author \\ sodipomope@yahoo.co.uk \\ TEL.: +23480600326123
}

Received: 14 December 2018; Published online: 24 February 2021

\begin{abstract}
Cookies are widely consumed all over the world and can bring important nutrients, especially to children. Composite flours consisting of plantain, moringa seed and sesame seeds were used to produce cookies in this study. Response surface methodology was employed in setting up the cookie's formulation. The samples with the best protein and fibre contents were sample $\mathrm{F}$ (71.34\% plantain, $6.66 \%$ moringa and $22.00 \%$ sesame seed, with $14.08 \%$ protein and $3.02 \%$ fibre) and sample I $(68.00 \%$ plantain, $10.00 \%$ moringa and $22.00 \%$ sesame seed, with $14.35 \%$ protein and $2.29 \%$ fibre). Cookies from $100 \%$ wheat flour were prepared as control. The protein, fat, ash and crude fibre contents of formulated cookies were significantly $(\mathrm{p} \leq 0.05)$ higher than control, whereas carbohydrate content was lower. There was no significant difference between the formulated cookies and the control in terms of overall acceptability, aroma and crunchiness. The formulated cookies showed higher biological value, net protein utilization, true digestibility, protein efficiency ratio, net protein ratio and protein retention efficiency than control, resulting in a significant increase in rat growth and development. The composite cookies containing unripe plantain, moringa seed and defatted sesame, at the blending ratio obtained in this study showed better nutritional quality than control cookies. These composite cookies, therefore, would be suitable for mitigating protein-energy malnutrition in children.
\end{abstract}

Keywords: Unripe plantain; Cookies; Protein quality

\section{Introduction}

Cookies have become one of the most desirable snacks for both youth and elderly people due to their low manufacturing cost, convenience to eat, long shelf-life and ability to serve as a vehicle for important nutrients (Akubor \& Ukwuru, 2003; Giarnetti, Paradiso, Caponio, Summo \& Pasqualone, 2015; Hooda \& Jood, 2005; Pasqualone, Bianco \& Paradiso, 2013).The fruit of plantain is very similar to that of banana except that it is less sweet and larger. It is often referred to as cooking banana and is a chief staple food in many parts of Africa (Muller, 1988). When plantain is matured but unripe, it has a high amount of dietary fiber $(8.82 \%)$ and resistant starch $(16.2 \%)$, micronutrients and helps to reduce blood sugar level, besides it is low in protein and fat (Ayodele \& Godwin, 2010). Defatted sesame flour contains protein $(55.70 \%)$, ash $(9.83 \%)$, crude fiber $(1.64 \%)$, total carbohydrate $(29.40 \%)$ and is high in sulphurcontaining amino acids (ElAdawy, 1997). Sesame increases plasma gamma-tocopherol and en- 
Cookies produced from unripe plantain, moringa seed and defatted sesame seed |SI73

hances vitamin E activity which is known to prevent cancer and heart disease (Bailey \& Hui, 1996). Moringa pods, flowers, fruits, leaves, roots and seeds are all useful in food and medicine, as they contain various valuable nutrients. Moringa seed contains essential amino acid and has a good fatty acid composition (Ogunsina, Radha \& Indrani, 2011). Considering the health benefits of unripe plantain, moringa and sesame flour, their incorporation as composite blends in the preparation of cookies may enhance the nutritional and health status of the consumers and reduce total dependence on wheat flour. This research aimed at evaluating the nutritional benefits and sensory quality of cookies produced from non-wheatcomposite flour.

\section{Materials and Methods}

\section{$2.1 \quad$ Materials}

Matured unripe plantain (Musa $A A B$ ), moringa seed (Moringa olifera), sesame seeds (Sesamum indicum) and baking ingredients including butter, salt, sugar, flavour, baking powder and eggs were purchased at Oja-Oba, Akure. Four-weekold weanling albino rats (Rattus norvegicus) were obtained from the Department of Health Sciences Animal House, Obafemi Awolowo University, Ile Ife, Nigeria.

\subsection{Preparation of unripe plantain, moringa and defatted sesame seed flours}

The unripe plantain and moringa seed flours were prepared by the method of Akubor and Ukwuru (2003) with little modification while defatted sesame seed flour was prepared by the method of ElAdawy (1997).

\subsection{Formulation of flour blends}

Composite flour formulation was designed using optimum mixture model of response surface methodology (Design expert 8.0.3.1, trial version) and is presented in Table 1. Unripe plantain, moringa and defatted sesame flours were the independent variables, while the dependent variable was the proximate composition (Table 2). The blends with the best protein and crude fibre contents were selected for subsequent analyses.

\subsection{Proximate Analysis of Flour Blends}

Proximate analysis for moisture, protein $(\mathrm{N} \mathrm{x}$ 6.25), fat, ash, and crude fiber of samples were determined according to AOAC (2005) procedures. Carbohydrate content was calculated by difference.

\subsection{Preparation of cookies}

Cookies were prepared according to the method of AACC (2000) with some modifications in the recipe: flour $250 \mathrm{~g}$, sugar $75 \mathrm{~g}$, vegetable shortening $100 \mathrm{~g}$, baking powder $2.5 \mathrm{~g}$, one egg, milk $30 \mathrm{~g}$, flavour $5 \mathrm{~g}$ and $5 \mathrm{ml}$ of water was added. The dry ingredients (flour, sugar, flavour, milk and baking powder) were thoroughly manually mixed in a bowl for $3 \mathrm{~min}$. Vegetable shortening was added and mixed until uniform. Egg was then added, and the mixture kneaded. The dough was rolled and cut with a $50 \mathrm{~mm}$ diameter cookie cutter. The cookies were placed on baking trays, leaving $25 \mathrm{~mm}$ spaces in between and were baked in an oven at $150^{\circ} \mathrm{C}$ for $30 \mathrm{~min}$. Following baking, the cookies were cooled at ambient temperature, packed in polyethylene bags and stored for subsequent analyses.

\subsection{Nutritional experiments}

Experimental isonitrogenous rodent diets containing $10 \%$ protein were prepared by incorporating the complementary foods and casein (control) into a basal diet prepared as described by Osundahunsi and Aworh (2003). The study was approved by the ethical review committee of the Federal University of Technology, Akure, Ondo State, Nigeria. Sixteen four-weekold weanling albino rats (Rattus norvegicus) obtained from the Department of Health Sciences Animal House, Obafemi Awolowo University, Ile Ife were weighed and divided into four groups

IJFS | February 2021 | Volume $10 \mid$ pages SI72-SI81 
Table 1: Mixture Design of Flour Blends from Response Surface Methodology (RSM)

\begin{tabular}{lccc}
\hline Run & Unripe Plantain $(\mathrm{g})$ & Moringa seed $(\mathrm{g})$ & Sesame seed $(\mathrm{g})$ \\
\hline 1 & 75.92 & 5.50 & 18.57 \\
2 & 78.00 & 5.00 & 17.00 \\
3 & 75.20 & 7.75 & 17.04 \\
4 & 72.85 & 5.15 & 22.00 \\
5 & 74.30 & 5.00 & 20.70 \\
6 & 71.34 & 6.65 & 22.00 \\
7 & 75.20 & 7.75 & 17.04 \\
8 & 70.11 & 8.81 & 21.06 \\
9 & 68.00 & 10.00 & 22.00 \\
10 & 72.85 & 5.15 & 22.00 \\
11 & 73.06 & 7.80 & 19.13 \\
12 & 78.00 & 5.00 & 17.00 \\
13 & 73.00 & 10.00 & 17.00 \\
14 & 73.00 & 10.00 & 17.00 \\
15 & 68.00 & 10.00 & 22.00 \\
16 & 71.08 & 10.00 & 18.91 \\
\hline
\end{tabular}

Table 2: Proximate Composition of composite flours

\begin{tabular}{lcccccc}
\hline Run & Moisture (\%) & Ash (\%) & Fibre (\%) & Protein (\%) & Fat (\%) & CHO (\%) \\
\hline A & 5.01 & 4.34 & 2.20 & 12.51 & 9.81 & 66.11 \\
B & 5.56 & 3.63 & 1.97 & 14.26 & 10.55 & 64.01 \\
C & 4.48 & 3.84 & 4.00 & 12.96 & 10.45 & 64.24 \\
D & 5.62 & 3.17 & 2.08 & 12.20 & 10.91 & 65.98 \\
E & 6.32 & 2.98 & 2.36 & 14.00 & 11.07 & 66.05 \\
F & $\mathbf{5 . 2 7}$ & $\mathbf{2 . 2 9}$ & $\mathbf{3 . 0 2}$ & $\mathbf{1 4 . 0 8}$ & $\mathbf{1 0 . 6 5}$ & $\mathbf{6 4 . 2 4}$ \\
G & 4.48 & 3.84 & 4.00 & 12.96 & 10.45 & 64.24 \\
H & 5.05 & 3.24 & 4.71 & 13.69 & 10.65 & 62.64 \\
$\mathbf{I}$ & $\mathbf{4 . 2 3}$ & $\mathbf{4 . 1 3}$ & $\mathbf{2 . 2 8}$ & $\mathbf{1 4 . 3 5}$ & $\mathbf{1 1 . 2 6}$ & $\mathbf{6 3 . 7 2}$ \\
J & 5.62 & 3.17 & 2.08 & 12.20 & 10.91 & 65.98 \\
K & 6.12 & 3.37 & 2.25 & 14.17 & 10.89 & 63.19 \\
$\mathbf{L}$ & 5.56 & 3.63 & 1.97 & 14.26 & 10.55 & 64.01 \\
$\mathbf{M}$ & 6.42 & 2.96 & 2.24 & 14.00 & 10.92 & 63.43 \\
$\mathbf{N}$ & 6.42 & 2.96 & 2.24 & 14.00 & 10.92 & 63.43 \\
O & 4.23 & 4.13 & 2.28 & 14.35 & $11 . .26$ & 63.72 \\
$\mathbf{P}$ & 6.02 & 2.94 & 2.24 & 13.65 & 9.87 & 65.26 \\
\hline
\end{tabular}


Cookies produced from unripe plantain, moringa seed and defatted sesame seed |SI75

(experimental, control and basal) and were acclimatized for a period of 7 days to the laboratory conditions prior to the experiment with free access to drinking water and pellet diets. The experimental animals were reweighed and regrouped to 4 groups so that the average weights were equal. Two groups were fed with different formulation of the diet (cookies) while the remaining groups were fed with casein as control and nitrogen free diet (basal diet) as presented in Table 3. The rats were housed in individual metabolic cages while water and food were supplied ad libitum for 21 days.

The weights of the animals and feed intake were recorded daily for 21 days. Faeces and urine samples were collected, and physical appearance of the animals was recorded. At the end of the test period, the animals were anaesthetized and sacrificed; the liver, kidney and heart were removed and weighed. The Protein Efficiency Ratio (PER), Net Protein Retention (NPR), Biological Value (BV), True Digestibility (TD), Net Protein Utilization (NPU) and mean weight gain were calculated.

\subsection{Sensory properties of cookies}

The organoleptic assessment of the cookies was carried out using twenty untrained panelists. A 9-point hedonic scale ranging from 9 (liked extremely) to 1 (disliked extremely) was used.

\subsection{Statistical analysis}

All analyses were conducted in triplicates. Mean scores of the results and their standard error of mean were reported using SPSS. Data was subjected to analysis of variances, and Duncan multiple range (Duncan, 1955) test was used to point out significant differences.

\section{Results and Discussion}

\subsection{Proximate composition of composite flour blends}

The proximate compositions of unripe plantain, moringa seed and defatted sesame flour are presented in Table 2. The formulations with high protein and crude fibre contents selected were sample $\mathrm{F}$ ( $71.34 \%$ plantain, $6.66 \%$ moringa and $22.00 \%$ sesame) consisting of $14.08 \%$ protein and $3.02 \%$ fibre and sample I $(68.00 \%$ plantain, $10.00 \%$ moringa and $22.00 \%$ sesame) consisting $14.35 \%$ protein and $2.28 \%$ fibre. The protein content of the flour blends was higher than that of the wheat flour; this may be due to the presence of the defatted sesame and moringa seed flours (Chinma, Igbabul, Omotayo et al., 2012). Also, the fibre content in the composite mixture of the flour blends was higher than wheat flour. It might be a result of incorporation of matured unripe plantain which contains more resistant starch, and hence, high fibre content (Ayodele \& Godwin, 2010).

\subsection{The proximate composition of cookies}

The proximate composition of cookies and control (100\% wheat flour) are presented in Table 4. It was observed that cookies from composite flour had higher protein, moisture, fat and ash contents than that of the control. The addition of defatted sesame and moringa seed flour could be responsible for the higher protein content of the composite flour (Ayo, Ayo, Popoola, Omosebi \& Joseph, 2014). The control had higher carbohydrate $(69.79 \%)$ compared with $64.23 \%$ and $61.41 \%$ of cookies from composite flour. The percentage fat content of the composite flour cookies increased from $10.66 \%$ to $16.65 \%$ in sample $\mathrm{F}$ and $11.27 \%$ to $17.82 \%$ in sample I. The increase may be due to the addition of vegetable shortening and some other ingredients such as milk used in the production of the composite flour cookies. The low values of moisture content obtained were in accordance with the report of Olagunju and Ifesan (2013) of low moisture in cookies produced from wheat and germinated sesame seed. This is desirable for long shelf life and it was below the maximum level of $(6 \%)$ recommended requirement of Nigerian Industrial Standard (NIS) for cookies by Standard Organization of Nigeria $(\mathrm{SON})$. The value of fibre was higher in sample F compared with control.

IJFS | February 2021 | Volume 10| pages SI72-SI81 
Table 3: The basic composition of the basal diet

\begin{tabular}{lc}
\hline Materials & Amount (\%) \\
\hline Vegetable oil & 10 \\
Vitamin premix & 1 \\
Mineral premix & 2 \\
Cellulose non-nutritive & 5 \\
Test protein casein (not included in nitrogen free diet) & 10 \\
Glucose & 5 \\
Sodium chloride & 0.25 \\
Bone meal & 2 \\
Oyster shell & 1 \\
Sugar & 10 \\
Corn starch(was added to make up to 100\%) & \\
\hline Osundahunsi and Aworh (2003) &
\end{tabular}

Table 4: Proximate composition of cookies (\%)

\begin{tabular}{lcccccc}
\hline Sample & Moisture & Fat & Crude Fibre & Protein & Ash & Carbohydrate \\
\hline F & $2.49 \pm 0.20^{a b}$ & $16.65 \pm 0.02^{b}$ & $2.25 \pm 0.03^{a}$ & $13.83 \pm 0.19^{a}$ & $2.56 \pm 0.21^{b}$ & $64.23 \pm 0.11^{b}$ \\
I & $3.14 \pm 0.16^{a}$ & $17.82 \pm 0.12^{a}$ & $1.93 \pm 0.24^{a}$ & $14.53 \pm 0.35^{a}$ & $3.49 \pm 0.04^{a}$ & $61.41 \pm 0.23^{b}$ \\
Control & $1.87 \pm 0.07^{b}$ & $14.95 \pm 0.11^{c}$ & $2.05 \pm 0.01^{a}$ & $9.54 \pm 0.22^{b}$ & $1.80 \pm 0.14^{c}$ & $69.79 \pm 0.32^{a}$ \\
\hline
\end{tabular}

Values on column with the same superscript are not significantly different. Key:

Sample F; cookies produced from unripe plantain $(71.341 \%)$, moringa $(6.659 \%)$ and sesame flour $(22 \%)$.

Sample I; cookies produced from unripe plantain (68\%), moringa (10\%) and sesame flour (22\%).

Control sample; cookies produced from $100 \%$ wheat flour.

\subsection{Sensory evaluation of cookies}

The sensory evaluation of the cookies produced from the selected formulations was carried out using a 9 point hedonic scale. The subjective result of 20 panelists on the cookies produced from unripe plantain, moringa seed and defatted sesame flour compared with cookies produced from $100 \%$ wheat is presented in Table 5 . The result shows that there was no significant different $(\mathrm{p} \leq 0.05)$ in the overall acceptability between the composite flour cookies 649 (71.34\% plantain, $6.66 \%$ moringa and $22.00 \%$ sesame flour) and cookies from $100 \%$ wheat flour 352 . There were no significant differences between the crunchiness and aroma of the three samples, which agreed with the result of Chinma et al. (2011) who used tigernut and pigeon pea for biscuits, while sample 352 (control) was preferable in colour and taste to the composite flour samples. Both the cook- ies from formulated and control were accepted for sensory evaluation. This is in accordance with the report of Olaoye and Oladoye (2007) on breadfruit flour biscuit. This cookie was gluten free so can serve as alternative for children and adults that are allergic to gluten in wheat flour that can cause celiac diseases (Caponio, Summo, Clodoveo \& Pasqualone, 2008).

\subsection{Nutritional evaluation of cookies}

Figure 1 shows the average weight of the animals. Group 1 fed with the basal diet experienced a significant decrease in weight while those groups fed with experimental diets group 2 (cookies $: 71.43 \%$ unripe plantain $+6.66 \%$ moringa seed + $22.00 \%$ defatted sesame seed) and group 3 (cookies: $68.00 \%$ unripe plantain $+10.00 \%$ moringa

IJFS | February $2021 \mid$ Volume 10 | pages SI72-SI81 
Cookies produced from unripe plantain, moringa seed and defatted sesame seed |SI77

Table 5: Sensory evaluation of cookies

\begin{tabular}{lccccc}
\hline Sample & Appearance & Aroma & Taste & Crunchiness & Overall acceptability \\
\hline 842 & $7.07 \pm 0.43^{b}$ & $7.87 \pm 0.27^{a}$ & $6.93 \pm 0.46^{b}$ & $8.00 \pm 0.35^{a}$ & $7.13 \pm 0.43^{b}$ \\
649 & $7.20 \pm 0.35^{b}$ & $7.40 \pm 0.41^{a}$ & $7.33 \pm 0.30^{b}$ & $8.13 \pm 0.27^{a}$ & $7.60 \pm 0.34^{a b}$ \\
352 & $8.40 \pm 0.16^{a}$ & $7.53 \pm 0.22^{a}$ & $8.53 \pm 0.19^{a}$ & $8.20 \pm 0.30^{a}$ & $8.40 \pm 0.24^{a}$ \\
\hline
\end{tabular}

Values on column with the same superscript are not significantly different. Keys: Sample 842: cookies from flour of unripe plantain $71.431 \%+$ moringa seed $6.659 \%+$ defatted sesame seed $22 \%$ ).

Sample 649: cookies from flour of unripe plantain 68\% moringa seed 10\%+ defatted sesame seed $22 \%$ ).

Sample 352: cookies from $100 \%$ wheat flour.

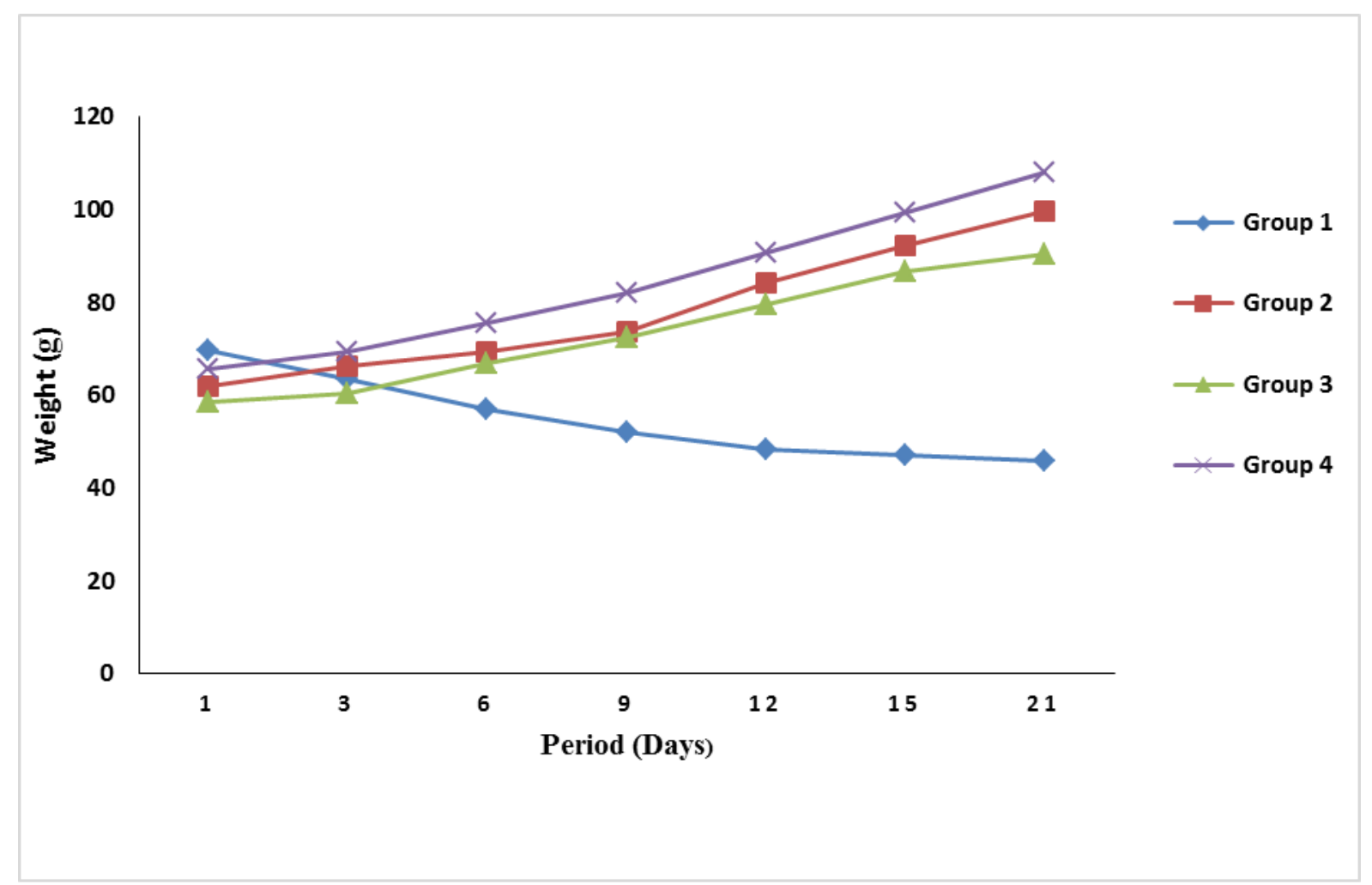

Figure 1: Average weight of the animals (g) 


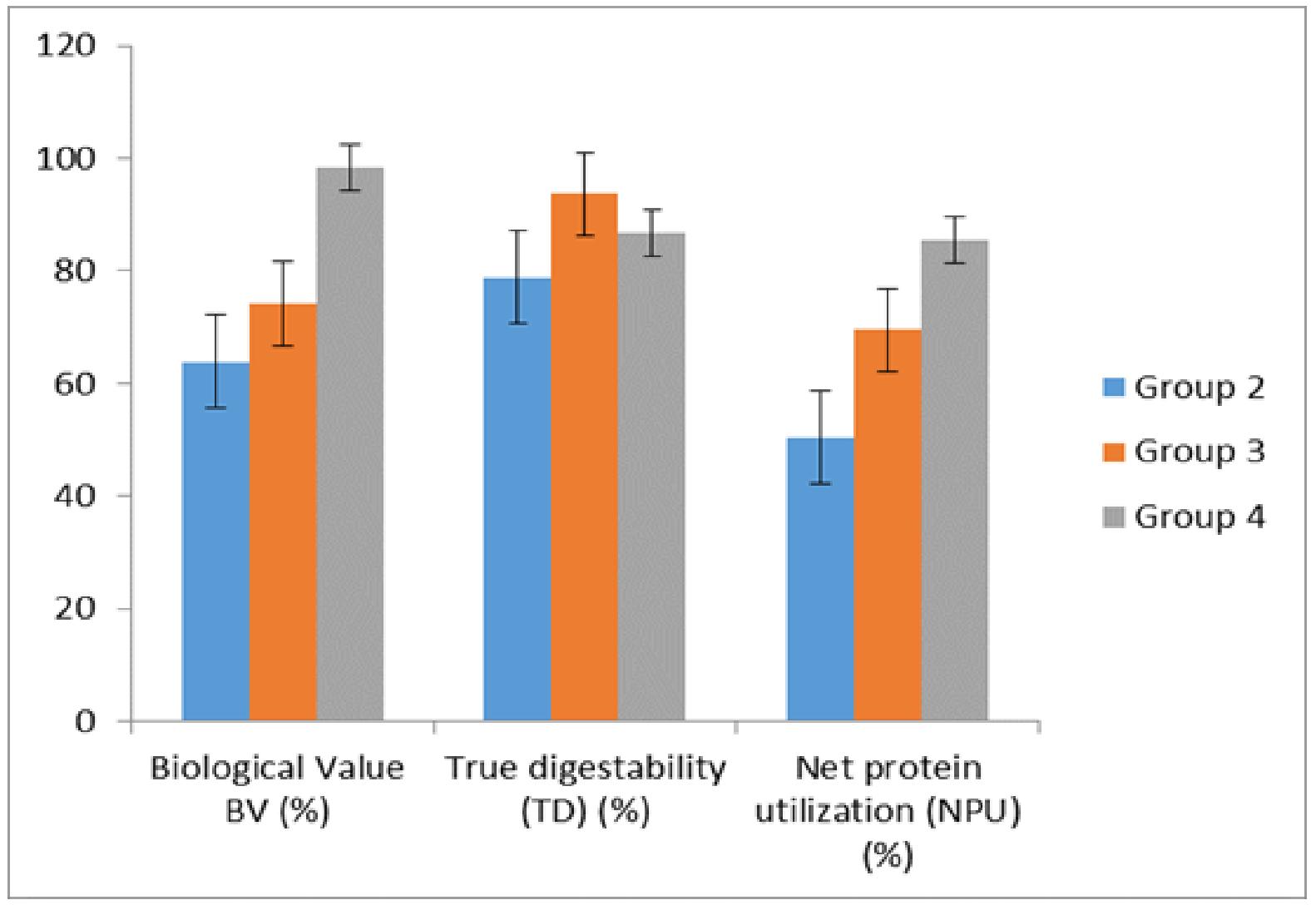

Figure 2: Biological value, true digestibility and net protein utilization of test diets and casein diet

Table 6: Protein quality indices of experimental animals

\begin{tabular}{lcccc}
\hline Indices & Group 1 & Group 2 & Group 3 & Group 4 \\
\hline Feed intake (g) & 262.90 & 260.80 & 235.80 & 330.60 \\
Feacal nitrogen & 5.6 & 6.48 & 5.84 & 6.30 \\
Urine nitrogen & 1.47 & 2.66 & 2.38 & 1.54 \\
Protein efficiency ratio (PER) & & 2.05 & 2.06 & 2.73 \\
Net protein ratio (NPR) & & 3.05 & 3.08 & 3.86 \\
Protein retention efficiency (PRE) & & 48.80 & 49.28 & 61.76 \\
\hline
\end{tabular}

\section{Keys:}

Group 1: animal fed with basal diet (nitrogen free)

Group 2: animal fed with cookies $(71.43 \%$ unripe plantain $+6.66 \%$ moringa seed $+22.00 \%$ defatted sesame seed)

Group 3: animal fed with cookies $(68.00 \%$ unripe plantain $+10.00 \%$ moringa seed $+22.00 \%$ defatted sesame seed)

Group 4: animal fed with $10 \%$ casein 
Cookies produced from unripe plantain, moringa seed and defatted sesame seed |SI79

Table 7: Average weight of animal organs

\begin{tabular}{lccc}
\hline Groups & Liver & Kidney & Heart \\
\hline Group 1 & $3.47 \pm 0.40^{a}$ & $0.58 \pm 0.07^{c}$ & $0.32 \pm 0.08^{a}$ \\
Group 2 & $4.24 \pm 0.25^{a}$ & $0.79 \pm 0.01^{a}$ & $0.39 \pm 0.03^{a}$ \\
Group 3 & $3.43 \pm 1.75^{a}$ & $0.69 \pm 0.03^{b}$ & $0.35 \pm 0.10^{a}$ \\
Group 4 & $4.03 \pm 1.20^{a}$ & $0.82 \pm 0.08^{a}$ & $0.36 \pm 0.03^{a}$ \\
\hline Values on column with the same superscript are \\
not significantly different. Keys: \\
Group 1: animal fed with basal diet (nitrogen free) \\
Group 2: animal fed with cookies (71.43\% unripe plantain \\
+ 6.66\% moringa seed + 22.00\% defatted sesame seed) \\
Group 3: animal fed with cookies (68.00\% unripe plantain \\
+ 10.00\% moringa seed + 22.00\% defatted sesame seed) \\
Group 4: animal fed with 10\% casein
\end{tabular}

seed $+22.00 \%$ defatted sesame seed), and with casein diets experienced an increase in weight. This agreed with Sodipo and Fashakin (2011); Ikujenlola and Fashakin (2005) in the preparation of complementary diets. The weight of rats fed with experimental diets was significantly different $(\mathrm{p} \leq 0.05)$ from rats fed with casein. There was increase in growth of the animals fed with experimental diets and casein. It was observed that there was an increase in weight of animals fed with experimental diets and a decrease in weight of animals fed with basal diets (nitrogen free diet), which was also in accordance with the report of Sodipo and Fashakin (2011). This indication shows that daily protein intake is essential for growth and development in humans, especially children. Table 5 shows the protein quality indices of the experimental animals. The animals fed with casein diets had highest PER, PRE and NPR. This agreed with the report of Abiose, Ikujenlola and Aboderin (2015) that casein had the highest value in PER. The PER and NPR obtained for the composite cookies agreed with the report of Adepeju, Abiodun, Dauda and Fatiregun (2016) that used soybean sesame ogi. Since, the protein efficiency ratio (PER), net protein ratio (NPR) and protein retention efficiency (PRE) are very important parameters for the determination of effective and efficient growth rate, cookies produced from the composite flour blends could be essential for growth and development of children, and also may serve as a means to reduce Protein-Energy Malnutrition (PEM) in children. The Biological Value (BV) of animals fed with casein diets (group 4) was higher than the BV of animals fed with experimental diets (group 2 and 3) as presented in fig 2. The True Digestibility of protein of animals fed with experimental diets, group 3, was the highest, followed by animals fed with casein diets (group 4), while animals fed with experimental diets, group 2, recorded the least true digestibility. Group 4 recorded the highest Net Protein Utilization (NPU) followed by group 3 and group 2, respectively. The higher the BV, TD, and NPU the better the protein quality, the standard for protein quality measurement ranged from 70 to $90 \%$ (Ali, El Tinay, Mallasy \& Yagoub, 2010). The result obtained for protein quality of animals fed with experimental diets indicated that the protein content present in the experimental cookies was well utilized and appeared to be significant in animal growth and development. The True Digestibility (TD) is a measure of total essential amino acid profile in the diet. The values obtained from animals fed with both experimental and casein diets ranged from 78.90 to 93.63 , which showed that the experimental and casein diets contain high numbers of essential amino acids. Table 6 shows the average weight of animal organs that include liver, kidney and heart. It was observed there were no significant differences in the weights of an- 
imal liver and heart within groups. The weight of group 2 and group 4 kidneys was not significantly different while group 1 and group 3 kidneys was significantly different from others. This could be as a result of the amount of food taken by the animal and components of the food.

\section{Conclusion}

It was observed that cookies produced from composite flour containing unripe plantain, moringa and sesame, had high protein content and were considered acceptable by the panelists in comparison with cookies made from wheat flour. The composite cookies also promoted growth of rats, due to high protein efficiency ratio and biological value. Therefore, cookies prepared from this composite flour may be used to ameliorate protein-energy malnutrition in children and can be found acceptable also by adults.

\section{References}

AACC. (2000). Approved Methods of the American Association of Cereal Chemists. 10th Edn., American Association of Cereal Chemists Press, St. Paul, MN., USA.

Abiose, S. H., Ikujenlola, A. V. \& Aboderin, F. I. (2015). Nutritional quality assessment of complementary foods produced from fermented and malted quality protein maize fortified with soy bean flour. Polish Journal of Food and Nutrition Sciences, 65(1), 4956. doi:10.1515/pjfns-2015-0004

Adepeju, A. B., Abiodun, A., Dauda, O. \& Fatiregun, A. (2016). Nutritional evaluation of weaning food prepared from fermented sorghum, germinated soybean and defatted sesame seed. School of Sciences, Federal University of Technology, Akure, Nigeria.

Akubor, P. I. \& Ukwuru, M. U. (2003). Functional properties and biscuit making potential of soybean and cassava flour blends. Plant Foods for Human Nutrition, 58(3), $1-12$.
Ali, M. A. M., El Tinay, A. H., Mallasy, L. O. \& Yagoub, A. E. A. (2010). Supplementation of pearl millet flour with soybean protein: Effect of cooking on in vitro protein digestibility and essential amino acids composition. International Journal of Food Science and Technology, 45(4), 740-744. doi:10 . $1111 / \mathrm{j} .1365-2621.2010 .02187 . \mathrm{x}$

AOAC. (2005). Official Methods of Analysis. 16th Edn., Association of Official Analytical Chemists, Washington, DC., USA.

Ayo, J. A., Ayo, V. A., Popoola, C., Omosebi, M. \& Joseph, L. (2014). Production and evaluation of malted soybean-acha composite flour bread and biscuit. African journal of Food science and Technology, 5(1), 21-28.

Ayodele, O. H. \& Godwin, E. V. (2010). Glycemic indices of processed unripe plantain (musa paradisiaca) meals. African Journal of Food Science, 4 (8), 514-521.

Bailey, A. E. \& Hui, Y. H. (1996). Edible oil and fat products: General applications. John Wiley \& Sons, Limited.

Caponio, F., Summo, C., Clodoveo, M. L. \& Pasqualone, A. (2008). Evaluation of the nutritional quality of the lipid fraction of gluten-free biscuits. European Food Research and Technology, 227(1), 135-139. doi:10.1007/s00217-007-0702-0

Chinma, C. E., Igbabul, B. D., Omotayo, O. O. et al. (2012). Quality characteristics of cookies prepared from unripe plantain and defatted sesame flour blends. American Journal of Food Technology, 7(7), 398-408.

Chinma, C. E., James, S., Imam, H., Ocheme, O. B., Anuonye, J. C. \& Yakubu, C. M. (2011). Physicochemical and sensory properties, and in-vitro digestibility of biscuits made from blends of tigernut (cyperus esculentus) and pigeon pea (cajanus cajan). Nigerian Journal of Nutritional Sciences, 32(1), 55-62.

Duncan, D. B. (1955). Multiple range and multiple F tests. Biometrics, 11(1), 1-42.

ElAdawy, T. A. (1997). Effect of sesame seed protein supplementation on the nutritional, physical, chemical and sensory properties of wheat flour bread. Food Chemistry, 59(1), 7-14. doi:10.1016/0308-8146(95) 00197-2 
Cookies produced from unripe plantain, moringa seed and defatted sesame seed |SI81

Giarnetti, M., Paradiso, V. M., Caponio, F., Summo, C. \& Pasqualone, A. (2015). Fat replacement in shortbread cookies using an emulsion filled gel based on inulin and extra virgin olive oil. $L W T$ - Food Science and Technology, 63(1), 339-345. doi:10.1016/j. lwt.2015.03.063

Hooda, S. \& Jood, S. (2005). Organoleptic and nutritional evaluation of wheat biscuits supplemented with untreated and treated fenugreek flour. Food Chemistry, 90(3), 427-435. doi:10.1016/j.foodchem.2004.05. 006

Ikujenlola, V. A. \& Fashakin, J. B. (2005). Bioassay assessment of a complementary diet prepared from vegetable proteins. Journal of Food Agriculture and Environment, 3(3/4), 20.

Muller, H. G. (1988). An introduction to tropical food science. Cambridge University Press.

Ogunsina, B. S., Radha, C. \& Indrani, D. (2011). Quality characteristics of bread and cookies enriched with debittered moringa oleifera seed flour. International Journal of Food Sciences and Nutrition, 62(2), 185-194. doi:10.3109/09637486.2010.526928

Olagunju, A. I. \& Ifesan, B. O. T. (2013). Nutritional composition and acceptability of cookies made from wheat flour and germinated sesame (sesamum indicum) flour blends. Current Journal of Applied Science and Technology, 702-713.

Olaoye, O. \& Oladoye, O. (2007). Breadfruit flour in biscuit making: Effects on product quality. African Journal of Food Science, 1.

Osundahunsi, O. F. \& Aworh, O. C. (2003). Nutritional evaluation, with emphasis on protein quality, of maize-based complementary foods enriched with soya bean and cowpea tempe. International Journal of Food Science and Technology, 38(7), 809813. doi:10.1046/j.1365-2621.2003.00736.x

Pasqualone, A., Bianco, A. M. \& Paradiso, V. M. (2013). Production trials to improve the nutritional quality of biscuits and to enrich them with natural anthocyanins. CYTA Journal of Food, 11(4), 301-308. doi:10 . 1080/19476337.2012.753113

Sodipo, M. A. \& Fashakin, J. B. (2011). Physico-chemical properties of a comple- mentary diet prepared from germinated maize, cowpea and pigeon pea. Journal of Food Agriculture ES Environment, 9(3-4, 1), 23-25. 